\title{
How Land Title Affects Child Labor?
}

Maurício J. S. B. Moura ${ }^{1} \quad$ Rodrigo De Losso da Silveira Bueno ${ }^{2}$

2009

${ }^{1}$ George Washington University and IDB. Email: mmoura@gwu.edu

${ }^{2}$ Professor Adjunto, EAESP-FGV: rodrigo.bueno@fgv.br 


\begin{abstract}
Secure property rights are considered a key determinant of economic development. However, the evaluation of the causal effects of land titling is a difficult task. The Brazilian government through a program called "Papel Passado" has issued titles, since 2004, to over 85,000 families and has the goal to reach 750,000. Furthermore, another topic in Public Policy, that is crucial for developing economies, is child labor force participation. Particularly, in Brazil, about 5.4 million children and teenagers between 5 and 17 years old are still working full time. This paper examines the direct impact of securing a property title on child labor force participation. In order to isolate the causal role of ownership security, this study uses a comparison between two close and very similar communities in the City of Osasco case (a town with 650,000 people in the São Paulo metropolitan area). The key point of this case is that some units get the program and others do not. One of them, Jardim Cana a, was fortunate to receive the titles in 2007, the other, Jardim DR, given fiscal constraints, only will be part of the program schedule in 2012, and for that reason became the control group. The estimates, generated using Difference-in-Difference (DD) econometric technique, suggest that titling results in a substantial decrease of child labor force participation for the families that received the title compared to the others. Such remarks can provide a relevant subsidize regarding future public tools to approach informality and affect economic growth.
\end{abstract}

Key Words: Property rights, land titling, child labor force

JEL: H27, H81, C21

Área Anpec: 04 


\section{Introduction}

The role played by private rights in the economic development of the Western world has been powerfully documented by economic historians such as North \& Thomas (1973). The fragility of property rights is considered a crucial obstacle for the economic development (NORTH, 1990). The main argument is that individuals underinvested if others can seize the fruits of their investment (DEMSETZ, 1967). Torstensson (1994) and Goldsmith (1995) found a significantly positive association between secure property rights and economic growth.

In such context, strengthening economic institutions is widely argued to foster investment in physical and human capital, bolster growth performance, reduce macroeconomic volatility and encourage an equitable and efficient distribution of economic opportunity (ACEMOGLU et al., 2002). In the current developing world scenario, a pervasive sign of feeble poverty rights are the 930 million people living in urban dwellings without possessing formal titles of the plots of land they occupy (United Nations, Habitat Report, 2005). The lack of formal property rights constitutes a severe limitation for the poor. The absence of formal titles creates constraints to use land as collateral to access the credit markets (BESLEY, 1995).

De Soto (2000) emphasizes that the lack of property rights limits the transformation of the wealth owned by the poor into capital. Proper titling could allow the poor to collateralize the land. Field \& Torero (2002) mentioned that this credit could be invested as capital in productive projects, promptly increasing labor productivity and income. Among policy-makers as well, property titling is increasingly considered one of the most effective forms for targeting the poor and encouraging economic growth (BAHAROGLU, 2002; BINSWANGER et al., 1995) as translated in the Figure I below. 


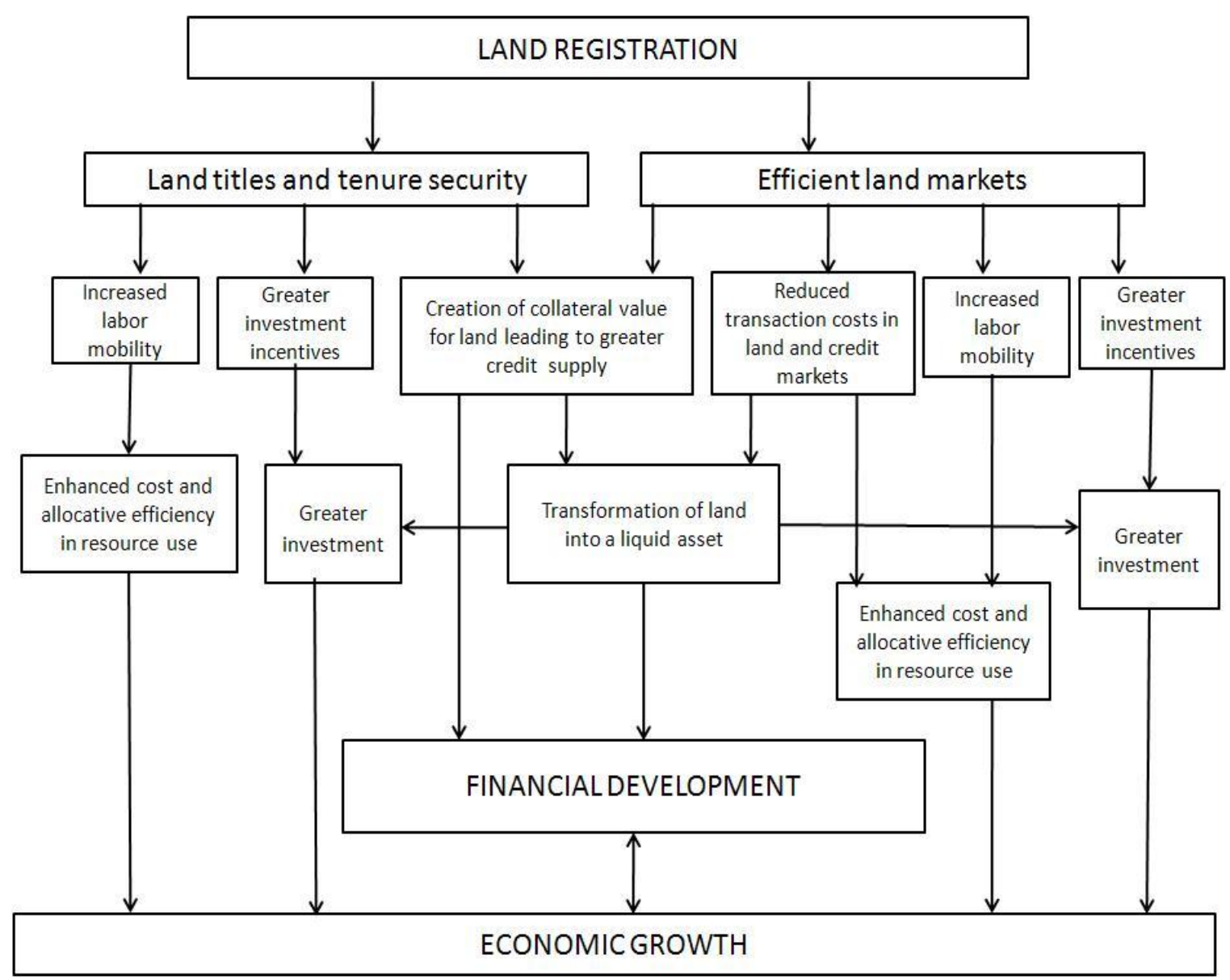

Figure I: Land Registration

Source: World Bank, 2000

The most famous example is Peru in Latin America. The Peruvian government issued property titles to 1.2 million urban households during the 1990's. In Asia, millions of titles are being issued in Vietnam and Cambodia as shown in the The Economist magazine in March 15th 2007 edition. The same edition brings in the front page: "Property Rights: China's Next Revolution". The survey shows that China intends to put into place the most ambitious land-titling program in the World's History and includes such initiative as one of the main points of the Chinese economic development model.

In Brazil, President Luiz Inácio Lula da Silva announced during his first week in the office, back in 2003, a massive plan to title 750,000 families all over the country. The Brazilian Federal Government created a program called "Papel Passado". Since launched, the program has spent US\$ 15 million per year from the Federal Budget, providing titles to over 85,000 and reaching 49 cities in 17 different Brazilian states. The official goal of the program is "to develop land title in Brazil 
and promote an increase in quality of life for the Brazilian population". However, the country still faces a very difficult scenario regarding land property rights: the Brazilian government estimates that 12 million people live under illegal urban conditions (IBGE, 2007).

Furthermore, child labor is major issue faced by the global economy. In Brazil, about 5.4 million children and teenagers between 5 and 17 years old are working as (PNAD, IBGE, 2007) shown.

This paper investigates the impact of property rights on labor markets in an emerging economy such as Brazil by analyzing household response regarding to child labor force participation to an exogenous changes in formal ownership status. In particular, the paper assesses the value to a squatter household of increases in tenure security associated with obtaining a property title in terms of hours of child labor supply.

Effects of land titling have been documented by several studies. A partial listing includes Jimenez (1985), Alston et al. (1996) and Lanjouw \& Levy (2002) on real estate values. Besley (1995), Jacoby et al. (2002), Brasselle et al. (2002) and Do \& Iyer (2003) on agricultural investment. Place \& Migot-Adholla (1998), Carter \& Olinto (2002) and Field \& Torero (2002) on credit access, housing investment and income.

In urban settings, the value of property titles has been measured far less often and empirical work has focused on real estates prices. A major contribution is from the of paper by Jimenez (1984), involving an equilibrium model of urban squatting in which it is shown that the difference in unit housing prices between non-squatting (formal) sector of a city and its squatting (informal) sector reflects the premium associated with security. The accompanying empirical analysis of real estate markets in Philippines finds equilibrium prices differentials between formal and informal sector unit dwelling prices in the range of $58.0 \%$ and greater for lower income groups and larger households.

For Besley (1995), the findings were ambiguous, land rights appear to have a positive effect on agricultural investment in the Ghananian region of Angola but less noticeable impact on the region of Wassa. Using a similar approach, Jacoby et al. (2002) find positive effects in China, where as Brasselle et al. (2002) find no effects for Burkina Faso. Field \& Torero (2002), in Peru, exploits timing variability in the regional implementation of the Peruvian titling program using cross-sectional data on past and future title recipients midway through the project, and also finds positive effects, particularly in the credit access and housing investments. In Brazil, Andrade (2006) using cross-section data from a sample of 200 families of the Comunidade do Caju, an urban poor community in Rio de Janeiro, has demonstrated an increase effect on the income of those that had received the land title.

A common obstacle, faced by all studies mentioned above, is how to measure the influence of tenure security considering the potential endogeneity of ownership rights as pointed by Demsetz (1967) and Alchian \& Demsetz (1973). Direct evidence of this is provided by Miceli et al. (2001), who analyze the extent of endogeneity of formal agricultural property rights in Kenya.

In order to isolate the causal role of ownership security, this study uses a natural experiment, basically a comparison between two neighbor and very similar communities in the City of Osasco (a town with 650,000 people located in the São Paulo - Brazil metropolitan area). Osasco is part of the Papel Passado's map has 6,000 families living under urban property informality. One of them, Jardim Cana ã, was fortunate to receive the titles in 2007, the other, Jardim DR, only will be part of the program schedule in 2012, and for that reason became the control group. Such approach enables a comparison of households in a neighborhood reached by the program with households in a neighborhood not yet reached.

Furthermore, the present research, different from the previous studies, is based on a panel data, 
from a random sample from Jardim Cana ̃̃ and Jardim DR, and produced from a two-stage survey with focus on the property right issue. The first part of the survey was collected in March 2007, before titles had been issued to Jardim Canaã and the second collected in August 2008, almost one year and half after the titles. As Ravallion et. al (2005) argues that the best ex-post evaluations are designed and implemented ex-ante - often side-by-side with the program itself.

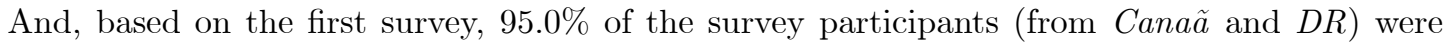
not aware about receiving land titles and the meaning of it (which avoids any behavior deviation generated by the expectation of having a land title). From the second stage of the survey, most of households that received the land title felt that such event was relevant for its life - see Figure II below even not previously expecting the land title.

\section{In a scale of 1 to 10 , considering 1 as no effect at all, and 10 if your life is really better because of the land title}

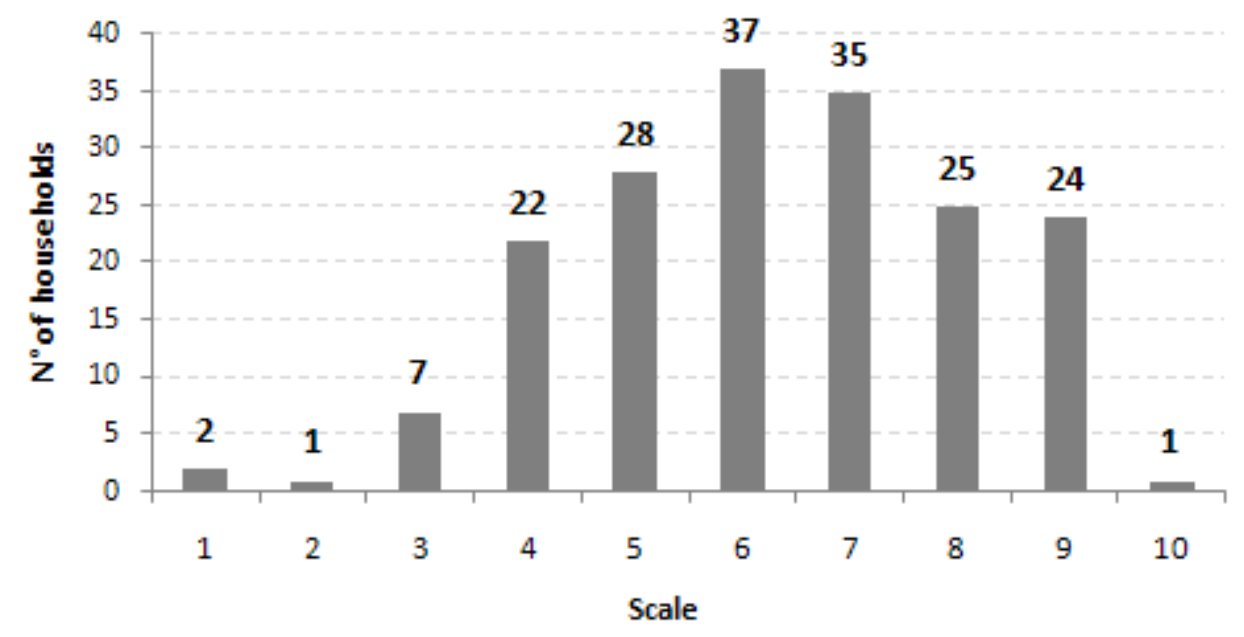

Figure II: How land title affected household's life?

Source: Research from the Osasco Land Title survey - 2008

Hence, an important contribution of this paper is the specific focus on non-agricultural households and the value to urban residents and their families of increased ownership security. As shown, in developing economies, large proportions of urban and rural residents alike lack tenure security. As Field \& Torero (2002) demonstrated, presumably because of historic interests in agricultural investment and related politics of land reform, the majority of both academic and policy attention to property rights has centered on rural households tenure security. Nevertheless, in most of the developing world, the population - and a particularly the impoverished population - is increasingly urban.

Secondly, this research provides an unique panel data through a natural experiment that helps to minimize the endogeneity aspect related to most of the studies on such subject (property rights). 
Third, many aspects have applied to try to explain the reasons of the child labor. The most commons are income, poverty, parent's level of education, parent's previous child labor experience, credit constraints and others. This paper intends to provide an additional aspect that can be used as part of the child labor causes explanation.

Last, but not least, this paper provides an initial impact measure, in terms of applied public policy, for the "Papel Passado" program and gives a partial feedback for policy-makers about the effects of land titling in variation of child labor force participation. Certainly, reducing child labor force participation is one of the main goals of the Federal and Local Governments. Social programs such as PETI (Programa de Erradicação de Trabalho Infantil), an initiative that focus on providing education opportunities for children engaged in labor activities and extra income for their poor families, is a great example of Government's concern. Understanding the potential positive effects of land titling and property rights in such subject could be valuable to make any effort related to child labor participation stronger and more effective.

\section{Child Labor Force Participation: The Economic Context}

Investing and focusing on human capital development is a critical factor to increase economic growth, as states Becker e Lewis (1973), and given such key assumption, The United Nations Millennium goals include eliminating child labor as crucial step into a better and equal world.

According to the International Labour Organization (2002), 246 million children and teenagers between 5 and 17 years old are engaged in child labor around the world. Furthermore, 75.0\% of those children work for their own family activities. Asia, Africa and Latin America are the continents that host most the child labor in the world. Asia has the highest number of children in terms of volume but Africa is the leader relatively to the total size of work force.

In Brazil, data from PNAD (IBGE, 2007) has shown that from a 44.7 million population between 5 and 17 years old, $10.8 \%$ (4.8 million) are directly involved in labor child. The worst region of Brazil regarding this subject is the Northeast, with $13.4 \%$ of $5-17$ year population working and Southeast holds the lowest average (7.9\%). Such statistics represents a positive evolution over the last 4 years (see Figure III below). 


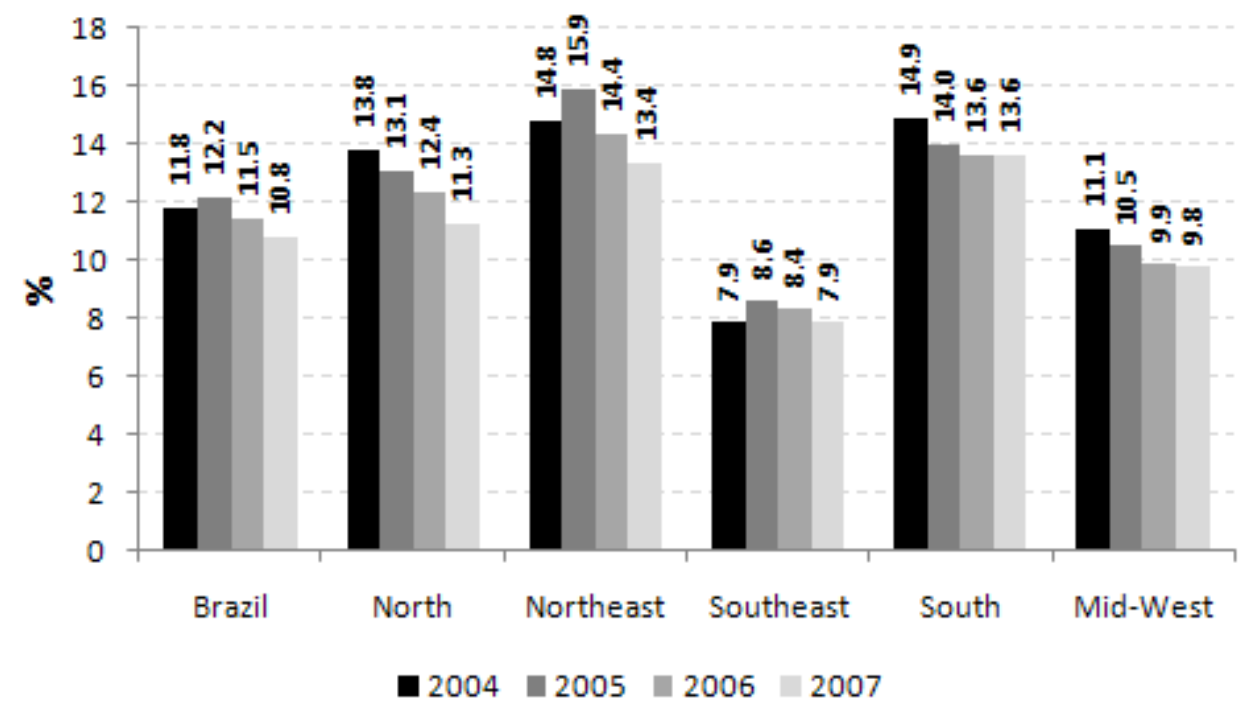

Figure III: Occupation level among the 5-17 year-old population (Percentual of total 5-17 population)

Source: IBGE, PNAD 2007

However, child labor is still a major issue for the Brazilian policy makers and PNAD (IBGE, 2007) also indicates that. For example, $60.0 \%$ of the children between 5 and 13 years old are related to non-paid activities. In the rural areas of Brazil, $40.0 \%$ of the $5-17$ years population works between 30 and 40 hours per week. In the Southeast, the richest region in the country, $30.0 \%$ of those work mentioned at least 40 hours per week.

The economic science has developed a range of potential theories to explain child labor. As Becker e Lewis (1973), child labor is an activity that generates current benefits in terms of income, but also creates future costs by reducing study and leisure. Given that, families evaluate costbenefits related to send their children to the school or to work. Rosenzweig (1981) has demonstrated that the children's time allocation depends on the production capacity of the children and its parents and the substitution degree of the work force between both.

Basu \& Van (1998) has built a model using one basic assumption: luxury. They consider that poverty is the main factor that makes parents sending children to work. Hence, the children's time that is not allocated (school and leisure) to generate income is luxury, and can not be afford by the low income parents. Ray (2001) has created a theory for emerging economies: child labor occurs mainly because of the poverty and the credit markets imperfections. He has shown that if poor families had access to credit, in the presence of high returns for education, they would willing to send children to school instead of work. Furthermore, the same study showed the relationship between income inequality and child labor under credit constraints. The main conclusion states that a more equal income distribution would reduce child labor.

Kassouf (2002) have demonstrated that an increase in the household's income reduces the prob- 
ability of child labor and increases the school attendance. Another element that affects the child labor probability is the parent's education degree. Bhalotra \& Heady (2003) found a negative effect given the mother's level of education and the child labor participation in Ghana. The effect the mother's education profile is higher comparing with the father. Kassouf (2002), in Brazil, has obtained the same negative effect. Family composition is another relevant factor for the particular analysis, Patrinos \& Psacharapoulos (1994) for Paraguay and Bhalotra \& Heady (2003) for Pakistan, concluded that more people in the family, higher the chances of having child labor.

Wahba (2002), using data from Egypt, showed a phenomena denominated "dynastic poverty traps" which means that the probability of children be sent to work increases $10 \%$ when their parents had worked during its childhood. Emerson \& Souza (2003) reached the same conclusion and explains such event as "social norms", parents that worked during its childhood years faces child labor more naturally. As mentioned earlier, this paper aims to provide an additional element for that discussion and test the relation between land titling and child labor force participation using the case of the City of Osasco.

\section{Microeconomic Framework - The Basic}

"I go to work with my children but my wife has to stay to look after the house" says Mr. Rosivaldo Reis, who sells popcorn and soft drinks in Downtown Osasco, São Paulo Brazil. Mr. Reis worries that people could size his house when he is away.

Cockburn (1998) pointed that one of the principal gains of strong property institutions is to shift the burden of property protection and enforcement away from individual households and informal communities to the State.

There is little microeconomic evidence documenting the cost of informality to individual households. Carter \& Zegarra (2000), World Bank (2000) and Field (2007) have noted that, in many settings, informal institutions arise to compensate for the absence of formal property protection. In such context, there one important mechanism by which it is assumed that tenure security removes individuals from the labor force and incremental income. Households untitled are constrained by the need to provide informal policing, both to deter prospective invaders from invading private properties and to actively participate in community enforcement efforts to protect neighborhood boundaries.

Hence, an important outcome of titling efforts that effectively increase household tenure security should allow households and communities to reallocate time, resources and human talent away from this role.

The acquisition of a property title has a direct value in terms of freeing up hours of work (and income generation) previously devoted to maintaining tenure security through informal means.

$$
I(\text { Income })=f\left(w ; H^{m}\right)
$$

$w=$ market wage

$H^{m}=$ work in the outside market

Assumptions:

a) There is no outside labor market for provision of home/tenure security. Assuming a missing labor market for the provision of home security is reasonably justified by incomplete contracts (there some risk involved in employing non-members to guard property - especially in those poor communities in Brazil). 
b) Leisure and home production hours are assumed to be perfect substitutes for the hours individual spend on property protection.

c) All households face a common wage $w_{i}$.

d) Household is assumed to maximize per capita leisure and not leisure of individual members.

e) Household talent $\Phi$ and endowment $(E)$ are assumed to be fixed.

Assuming, $Z=$ time spent at home $=H^{h}+L$

$H^{h}=$ work at home and $L=$ leisure

$N$ is the number of household members, $l_{i}$ is leisure, $x_{i}$ consumption, $H^{h}$ work hours in home production, and $H^{m}$ outside market work hours of household member $i$, and $x_{i}=X / N, l_{i}=L / N$.

Value of work at home is given by production function $q\left(H^{h}\right)$ and $\mathrm{w}$ is the value of work outside or market wage.

Household utility is an increasing function of per capita leisure $\left(l_{i}\right)$; per capita consumption $\left(x_{i}\right)$, and home security tenure $(S)$ ( $S=$ home tenure security function) and also concave.

While the tenure security function implies that the production of home security is only determined by exogenous variable $\Omega(\Omega=$ exogenous parameter, household formal property rights) and the amount of time spent in the home.

Given the set of talent $\Phi$ and endowment $E$ :

$U\left(x_{i}, l_{i}, s: \Phi, E\right)$ where $S=S(Z, \Omega)$

Maximizing the utility function: $U\left(x_{i}, l_{i}, S: \Phi, E\right)$ where $S=S(Z, \Omega)$, where the endogenous variables are $H^{h}, H^{m}, x_{i}, l_{i}$, and $S$.

Budget $(p X)$ and time $(T)$ constraints to the maximization problem:

$$
\begin{gathered}
S=S\left(H^{h}+L, \Omega\right) \\
p X=\omega H^{m}+q\left(H^{h}\right) \\
T=L+H^{h}+H^{m}=Z+H h
\end{gathered}
$$

Assumption: $L, H^{h}, H^{m}, x_{i} \geq 0$

Where $q($.$) satisfies the decreasing marginal productivity \left(q^{\prime}>0, q^{\prime \prime}<0\right)$. Then, normalizing prices to one, household's optimization problem:

$$
\operatorname{Max}_{\left(H^{h}, H^{m}\right)} U\left(\frac{1}{N}\left(\omega * H^{m}+q\left(H^{h}\right)\right), \frac{1}{N}\left(T-H^{m}-H^{h}\right), S\left(T-H^{m}, \Omega\right)\right)
$$

This equation requires the following first-order conditions for an interior solution $\left(H^{m}>0 ; H^{h}>\right.$ $\left.0 ; H^{m}+H^{h}<T\right)$ :

$$
\begin{gathered}
\frac{\omega}{N} * U x i=\frac{1}{N} * U_{l_{i}}+U_{s} * S H^{m} \\
q H^{h} * U_{x_{i}}=U_{l i}
\end{gathered}
$$

Equation 1 establishes that, at the optimum, households equate the marginal value of an additional hour of outside labor with the marginal utility of leisure. Equation 2 states that they also equate the marginal utility of leisure with the marginal value of an additional hour of work at home. 
Given such context, demand functions of work hours in the outside market and in home production which depends on $\Omega$ and $\omega$ :

$$
H^{h}=H^{h}(\Omega, \omega), H^{m}=H^{m}(\Omega, \omega)
$$

Assume that $U_{x s_{i}} \geq 0, U_{x_{i} l_{i}} \geq 0, U_{l_{i} s} \geq 0$

In that case, households ability to increase security by staying close to home implies that optimal allocation of work hours across home and market will depend on the formal tenure rights. In particular, maximizing the above utility function subject to basic budget and time constraints mentioned above generates the following inequalities:

$$
\frac{\partial H^{h}}{\partial \Omega}<0 \text { and } \frac{\partial H^{m}}{\partial \Omega}>0
$$

For households involved in both type of labor, an increase in formal tenure security decreases work hours at home and increases work hours in the outside market.

The conditions imply that, in aggregate, strengthening formal property rights decreases work hours inside the house and increases time spent outside, reflecting the fact that exogenous increase in the formal property protection, lowering the opportunity cost of outside labor and making stronger the probability to increase current income of those households as presented on $I($ Income $)=$ $f\left(w ; H^{m}\right)$.

In the empirical analysis, data limitations prevent from separating employment hours inside and outside home. Given that, and with the respect to the net effect of a property title on total labor hours, the model predicts that households with zero home production hours ex-ante $\left(H^{h}=0\right)$ will increase total household work hours by some positive amount in response to land title and property rights and decreases child labor hours.

\section{Microeconomic Framework - Labor Supply of Children}

An extension of the model, and significant part of the present study approach, incorporates differences in the household supply of adult and child labor when only adults contribute to home security provision. This extension formalizes the intuitive idea that, if adults have comparative advantage in the provision of home security, in the absence of property rights, children will substitute for adults in the labor market. In this case, while total household labor hours rise with an increase in formal rights - as demonstrated above, child labor hours will actually fall. Here, $N_{a}$ and $N_{c}$ are the number of adult and child household members, respectively, $l_{a}$ and $l_{c}$ are per capita adult and child leisure, $L_{a}$ and $L_{c}$ are total adult and child leisure and $T_{a}$ and $T_{c}$ are total adult and child time endowments. In this setting, the household maximization problem is:

$\max _{l_{a}, l_{c}, x} U\left(x, l_{a}, l_{c}, s\left(L_{a}, \Omega\right)\right)$ such that $W_{a} *\left(T_{a}-L_{a}\right)+W_{c} *\left(T_{c}-L_{c}\right)=X$

The first order conditions corresponding to each employed adult member $i$ and child $j$ are:

$$
\begin{gathered}
U_{l a i}=\left(\frac{-W a}{N}\right) * U x+\left(\frac{1}{N a}\right) * U_{l_{a}}+U s * s_{l_{a}}=0 \text { adult } \\
U_{l_{c_{i}}}=\left(\frac{-W c}{N}\right)+U x+\frac{1}{N c} * U_{l_{c}}=0 \text { child }
\end{gathered}
$$

From these conditions it can be shown that, for all interior optima, $\frac{\partial l_{c}}{\partial \Omega}>0$, and $\frac{\partial l_{a}}{\partial \Omega}<0$. 
In households in which children are labor force participants, child labor hours will fall and adult labor hours will rise with an increase in tenure security. For all other households, adult labor hours will rise and child labor hours will remain at zero. Thus, given a positive amount of ex-ante child labor, the aggregate number of child labor hours will unambiguously fall, while the number of adult hours rises with an increase in property rights.

Although this model focuses on optimal labor allocation, the income effect that follow from relaxing the household time constraint provide a plausible alternative explanation for a decrease in child labor with an increase in formal rights, and one that has been proposed by other authors. In particular, a decrease in the child labor would follow from the luxury and axioms of the Basu \& Van (1998) model of labor supply, in which children can substitute for adults in the labor market and a family will send children to the labor markets only if the family's income from non-child labor sources falls below some threshold amount.

\section{The Data}

The empirical analysis of household labor supply and income responses to changes in formal property rights relies on a data survey developed, especially and exclusive for this paper, in the City of Osasco, an important town in the São Paulo metropolitan area with a population of 654,000 people.

The Federal Government has chosen Osasco, as one of the participants of the "Papel Passado"a program that intends, as mentioned earlier in the paper, to provide land titles to families living under illegal conditions - given its relevant economic and social role.

The city of Osasco has 30,000 people (about 6,000 families) living under informal conditions, which represents almost $4.5 \%$ of its total population. The program timetable for Osasco establishes that all the communities under illegal situation will be part of the "Papel Passado" during the period between 2007 and 2014 (the main reason because all communities are not receiving the land title at the same time relies on the fact that fiscal resources are limited in time). Officially, as released by the Osasco City Hall, the priority follows random criteria. Unofficial sources from local communities in Osasco express the feelings that a "political" agenda is present in the decision.

Anyway, the first community to receive the land title was Jardim Canaãa, in 2007, a place with 500 families. The closest neighbor of Jardim Canaã is a community called DR, with 450 families. The DR's households will be part of the "Papel Passado" program schedule in 2011. Hence, the data of this particular paper consist in 326 households distributed across Jardim Cana a and DR (185 from Jardim Canaã and 141 from DR).

\section{A. Minimizing Endogeneity Bias Concerns}

Given the particular nature of the research conducted in the city of Osasco, some steps were taken to minimize the bias related with the data collected.

First of all, a technique from Bolfarine \& Bussab (2005) was used to choose randomly 326 sample households. The approach was basically to choose the first 150 households (from the Canaã and $D R$ ) that have the closest birth dates (day and month) in comparison with the three field researchers that conducted the survey interviews (important to mention that the field researchers are not from

Osasco). Each researcher got 50 names initially as first base. Additionally, after reaching each of those households, they could go and pick the third and the fifth neighbor on the right hand side. 
Secondly, Heckman \& Hotz (1989) states that constructing counterfactuals is the central problem in the literature evaluating social programs given the impossibility of observing the same person in both states at the same time. The goal of any program evaluation is to compare only comparable people. An important step to minimize such issue in this study was to use a comparison between

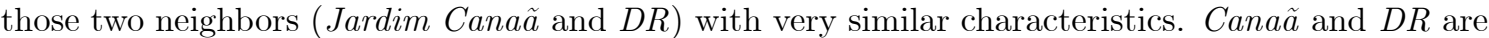
not only official neighbors but there is no physical "borderline" among them, both are geographically united (if someone walks there, it is hard to identify the boundaries - even for the local households).

One of them, Jardim Canaã , fortunate to receive the titles in 2007, is qualified, for the paper proposal, as the main sample. The other, $D R$, only part of the program schedule in 2011, became the control group. Such approach enables a comparison of households in a neighborhood reached by the program with households in a neighborhood not yet reached and gives the possibility to produce a panel data.

Another aspect to be mentioned about the data collected is that produced an unique match within same geographic area which helped to assure that comparison units come from the same economic environment. Rubin \& Thomas (2000) indicate that impact estimates based on full (unmatched) samples are generally more biased, and less robust to miss-specification of the regression function, than those based on matched samples.

Given such conditions, it was produced from a two-stage survey focused on the property right issue. However, to minimize bias, the way that survey was prepared and conducted by the researchers does not provide any direct information for the households what exactly the research is about. Officially for the people interviewed, the study was about City of Osasco general living conditions.

The survey was based on a 39 questions questionnaire applied to the 326 families randomly sample described above. The survey instrument, in many questions and methodologies, closely mirrors the IBGE Living Standards Measurement Survey (PNAD - Pesquisa Nacional de Amostra de Domicílios do Instituto Brasileiro de Geografia e Estatística) in content, and therefore contains a variety of information on household and individual characteristics. In addition, there are six questions designed to provide information on the range of economic, social and personal benefits associated with property formalization (Please refer to Appendix A for the complete stage I and stage II questionnaires).

The first stage of the survey was conducted in March 2007, before titles had been issued to Jardim Canaã and the second collected in August 2008, almost one year and half after the first title issued (with exactly same households and with $98.0 \%$ of recall - or $2.0 \%$ missing, which means, that almost all households interviewed in the first survey had been found and interviewed during the second stage). The reason regarding such time gap was to give the opportunity to all households interviewed during the first survey stage to have, at least, 1 year with the land title. The exactly dates that each household interviewed received the title were provided by the 2nd Cartório de Osasco (2nd Osasco's Office of Registration) along with the formal authorization from the Osasco's City Hall to conduct the research.

Heckman \& Hotz (1989) add that is not necessary to sample the same persons in different periods - just persons from the same population. This particular survey instrument design has clearly the advantage that the same households were tracked over time to form a panel data set Ravallion et al. (1995) argues that making a panel data with such characteristics should be able to satisfactorily address the problem of miss-matching errors from incomplete data, a very common issue regarding public policy evaluation.

Furthermore, it is also important to emphasize again another aspect that helps minimize the 
selection bias. Based on the first survey, $95.0 \%$ of the survey participants (from Canaã and DR) did not expect to receive any land title, i.e., they were not aware about "Papel Passado" and the meaning of it. Such lack of information about the subject provides the study a non-bias aspect regarding the importance of property rights because avoids a potential behavior deviation from households included in the program.

Finally, the study also tracks the households that moved outside both communities to check if the land title effect stands. From the original sample only $8.0 \%$ of the households that received the land title have moved away from Canaã (one of the main concerns from local authorities in Osasco was that most citizens would receive the land title, sell the property right away and return to an informal living conditions and that not has been materialized). From the control group, only 1 household (out of 140) has moved during the same period.

\section{Basic Findings - Child Labor Force}

This study has used basically four questions to address the issue of child along the survey. The first question was: "Do you have any children?" (Please refer to Appendix A for the complete stage I and stage II questionnaires). Combined sample and control group, about $75.0 \%$ of the households declared to have children (about $73.0 \%$ sample and $76.0 \%$ control group).

After the initial question mentioned above, the survey included the following: a) "Are there any children helping in the familiar income? How many? (under 18 years old)", b) "How many hours they work daily?" and c) "How many days per week minors work?". On top of that, from those households that have children, $25.5 \%$ responded that have minors helping the familiar income.

Additionally, the diagram below summarizes the household's answers (2007 and 2008) about weekly hours of child labor. The main issue that arises is related to the fact that for the sample is visible that children are working lower hours (and even households that have children working in 2007 changed path in the survey's second round) and for the control group the scenario gets worst over time. 


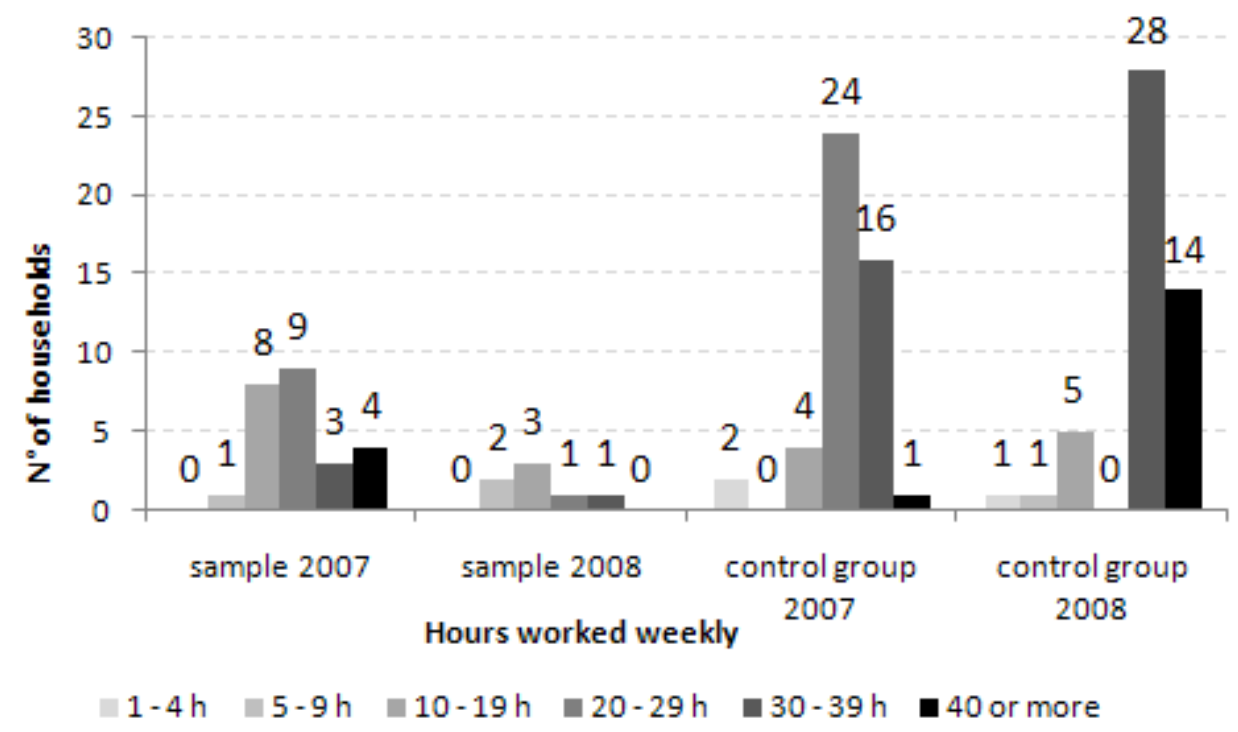

Figure IV: Child Labor Force Hours Worked Weekly x Number of Households Source: Research from the Osasco Land Title survey - 2008

\section{Econometric Model: Difference-in-Difference Estimates}

\section{A. Difference-in-Difference Estimates: Estimator - General Framework}

The econometric method used was Difference-in-Difference Estimate, known as DIFF-in-DIFF (DD), given the data characteristics described above. As Bertrand et al. (2004) defines, Differencesin-Differences consists of identifying a specific intervention or treatment (often a passage of a law). One then compares the difference in outcome after and before the intervention for groups affected by intervention to the same for unaffected groups.

Such approach involves basically two regimes: "0" and "1" given an observed outcome $Y$, which means $Y_{1}=d Y_{1}+(1-d) Y_{0}$. Given $d=1$, we observe $Y_{1}$ and with $d=0, Y_{0}$ is observed.

As Heckman \& Hotz (1989) stated that the parameter most commonly invoked in the program evaluation literature, although not the one actually estimated in social experiments is the effect of randomly picking a person with characteristics $X$ and moving from "0" to " 1 ":

$$
E\left(Y_{1}-Y_{0} / X\right)=E(\Delta / X)
$$

In practice, most non-experimental and experimental studies do not estimate $E(\Delta / X)$. Instead, studies usually estimate the effect of treatment on the treated.

$$
E(\Delta / X), d=1
$$


Given the data characteristics, this particular study aims, as previously mentioned, to provide a comparison between "treated" and "untreated" to estimate impact of treatment on the treated with a counterfactual.

Again as Heckman \& Hotz (1989) pointed, it is impossible to form change in outcomes between "treated" and "untreated" states for anyone. However, it is possible to form one or the other terms for everyone with the counterfactual mechanism.

Under such scenario, the current study also has the "before-after" estimator which incorporates time $t$ on the model.

Let's assume that the program/treatment occurs only at the time period $k$ and $t>k>t$.

Furthermore, $y_{i t}$ is the "treated" group at period $t$, if $i=1$ and "untreated" if $i=0$. Additionally, consider $d=1$ is the "treated" group and $d=0$ the "untreated" group.

Hence, the main focus is to estimate the follow:

$$
E\left(y_{1} t-y_{0} t \mid d=1\right)=E\left(y_{1} t-y_{0} t\right)_{1}
$$

and given that, it is possible to decouple the equation above between "treated" and "untreated" given two different periods, or $t>t$. The Difference-in-Difference estimator is:

$$
E\left(y_{i t}-y_{0} t\right)_{1}=E\left(y_{i} t-y_{0} t \prime\right)_{1}-E\left(y_{0} t-y_{0} t \prime\right)_{1}+E\left(y_{0} t-y_{0} t \prime\right)_{0}-E\left(y_{0} t-y_{0} t \prime\right)_{0}
$$

And, the assumption is:

$$
E\left(y_{0} t-y_{0} t \prime\right)_{1}=E\left(y_{0} t-y_{0} t \prime\right)_{0},
$$

Which basically means the between periods $t$ and $t$,the variation of the "treated" and "untreated" averages are the same. Hence:

$$
E\left(y_{1} t-y_{0} t\right)_{1}=E\left(y_{1} t-y_{0} t \prime\right)_{1}-E\left(y_{0} t-y_{0} t \prime\right)_{0}
$$

Given the fact that there is no treatment at $t$, the "treated" differentiates from the "untreated" as $\left(y_{0} t \prime \mid d=1\right)=y^{1} t \prime$ and $\left(y_{0} t \mid d=0\right)=y^{0} t \prime$. Following the equation above:

$$
E\left(y_{1} t-y_{0} t\right)_{1}=E\left[\left(y^{1} t-y^{1} t \prime\right)-\left(y^{0} t-y^{0} t \prime\right)\right]=E\left(\Delta y_{1}-y_{0}\right)
$$

Finally, the estimator can expressed as follow:

$$
\Delta y=d \Delta y_{1}+(1-d) \Delta y_{0}=\Delta y_{0}+d\left(\Delta y_{1}-y_{0}\right)
$$

Given the case the $\Delta y_{i}=\Delta X \beta_{i}+u_{i}$, the regression is:

$$
\Delta y=\Delta X \beta_{0}+d\left(\Delta X \beta_{1}-\Delta X \beta_{0}\right)+u_{0}+d\left(u_{1}-u_{0}\right)
$$

Assuming that $\beta_{1}-\beta_{0}=0$, except for the constant, follows:

$$
\Delta y=\Delta X \beta_{0}+d \alpha+u_{0}+d\left(u_{1}-u_{0}\right)
$$

and $\alpha$ is the focused parameter. 


\section{B. Difference-in-Difference Estimates: The Basic Regression Model}

Difference-in-Difference estimates and their standard error, according to Greene (2002), most often derive from using Ordinary Least Squares (OLS) in repeated cross sections (or a panel) data on individuals in treatment and control groups (no treatment) for a period before and after a specific intervention. As Meyer (1995) argues that the great appeal of DD estimation comes from its simplicity as well its potential to circumvent many of the endogeneity problems that typically arise when making comparisons between individuals.

The standard DD estimates the following regression:

$$
Y i s t=A s+B t+c X i s t+\beta I s t+\varepsilon i s t
$$

Where $A s$ and $B t$ are fixed effects for states and years respectively, Xist are relevant individual controls and $\varepsilon i s t$ is a error term. The estimated impact of the intervention is the OLS estimate $\widehat{\beta}$. Standard errors used to form confidence interval for $\widehat{\beta}$ are usually OLS standard errors sometimes corrected to account correlation of shocks within each year. Considering the data characteristics mentioned earlier, this study will assume that the estimated coefficient of intervention is variable (given $X i s t$ ) but does not help to determine program participation (land title were given randomly and households were mostly unaware about receiving the title).

Hence, this specification is a common generalization of the most basic DD, and it will be the foundation for this particular study econometric technique. The basic assumption is that changes in outcome variable over time would have been exactly the same in both treatment and control group in the absence of intervention.

\section{Difference-in-Difference Estimates: Land Title Specification}

In this paper, formally, the dependent variable is hours weekly hours of work of child labor force $Y$ ist (the outcome of interest for household $i$ in group $s$ by time $t$ ). The dependent variable would be posted as the difference among weekly hours of child labor in 2008 and 2007.

Also, $\delta$ indicates whether the household lives in a neighborhood that has been reached by the program - being the dummy for whether the land title has affected the group $s$ at the time $t$; with fixed effects and $X i$ is a vector of characteristic controls.

Hence, the coefficient $\delta$ is the estimated of program effect, which provides a measure of conditional average difference in time worked by child households in program area versus the non-program area.

In addition, $X i$ includes the following controls: sex (dummy), marital status (dummy, example: single) and ethnicity (dummy, example: African Brazilian).

Another set of variables included, to extend to include fixed effects, and convergent with Becker \& Lewis (1973) suggestion, are level of income - measured in terms of minimum wage (please refer to question number P-38 at Appendix A for details). Furthermore, weekly hours of adult work is an essential variable to understand child labor according to Rosenzweig (1981).

Patrinos \& Psacharapoulos (1994) for Paraguay, Grootaert (1998) for Gana and Heady (2003) for Pakistan, all of them concluded that more people in the family, higher the chances of having child labor. Given such framework, number of household members is also included. The same applies for the years of education of the family head. For income, weekly hours, number of household members and years of education, also the difference between the survey collection results in 2008 and 2007 is 
applied (example: the independent variable of income is = Income 2008 - Income 2007 and so on with the other variables mentioned).

As a robustness check, this study also estimates a regression including the households that moved from Cana a (households that got the title, sold the property and moved right away). The goal is to check if the land title still has positive effect even considering those that are not living in the original community.

Given all the conditions mentioned above, the basic econometric structure is the following:

$Y i=\alpha+\delta($ Land title $)+\beta($ Hours worked weekly - adult $)+\beta($ Income $)+\beta($ Households number $)+$ $\beta($ Years of education $)+\alpha^{\prime} X i+e i$

Furthermore, the main hypothesis to be tested is the following:

$H_{0}=\delta<0$

$H_{1}=\delta \geq 0$

\section{Results}

The summary of basic statistics results are presented in Table 1 (Sample Means). Consistent with the study basic findings, one main aspects demands special attention. The average weekly hours of child labor force has decreased from the program households and increased for the nonprogram. Additionally, for land title owners, weekly hours worked of adults increase more. Such could provide a potential signal that child labor is being substituted by adult work.

\begin{tabular}{lcccccc}
\hline & \multicolumn{3}{c}{ Pre-Program (N=251) } & \multicolumn{3}{c}{ Post-Program (N=240) } \\
& $\begin{array}{c}\text { Ia } \\
\text { (program) }\end{array}$ & $\begin{array}{c}\text { Ib } \\
\text { (non-prog) }\end{array}$ & $\begin{array}{c}\text { Ic } \\
\text { IIa }\end{array}$ & $\begin{array}{c}\text { IIa } \\
\text { IIb }\end{array}$ & $\begin{array}{c}\text { IIc } \\
\text { (program) }\end{array}$ & $\begin{array}{c}\text { (non-prog) } \\
|t \Delta|\end{array}$ \\
\hline Mean age & 42.0 & 45.0 & -3.0 & 42.8 & 45.9 & -3.1 \\
Time in residency (\# months) & 146.2 & 158.4 & -12.1 & 157.8 & 175.0 & -17.1 \\
Households number (\# members) & 3.8 & 4.0 & -0.2 & 3.9 & 4.1 & -0.2 \\
Number of rooms & 3.3 & 3.7 & -0.4 & 3.3 & 3.7 & -0.3 \\
Income (number of MW) & 2.0 & 3.0 & -1.0 & 2.0 & 3.0 & -1.0 \\
Years of Education & 9.0 & 5.0 & 4.0 & 9.0 & 5.0 & 4.0 \\
Hours Worked Weekly & 9.8 & 9.2 & 0.5 & 19.5 & 10.0 & 9.5 \\
Child Labor Hours Weekly & 3.5 & 9.1 & -5.6 & 0.5 & 11.9 & -11.4 \\
\hline
\end{tabular}

Table I: Sample means - with all households that have children

Source: Author's Estimates 


\begin{tabular}{c|cc}
\hline \hline & \multicolumn{2}{|c}{ Dependent variables } \\
\hline Independent variables & $\begin{array}{c}\text { Child Labor } \\
\text { (hours worked weekly) }\end{array}$ & $\begin{array}{c}\text { Child Labor } \\
\text { (with households that moved) }\end{array}$ \\
\hline Robustness check \\
\hline Constant & 5.66 & 5.62 \\
Sex & $(1.92)$ & -0.11 \\
Single & 0.39 & $(0.97)$ \\
African Brazilian & $(0.90)$ & -4.23 \\
& -3.38 & $(1.77)$ \\
Years of Education & -3.20 & -3.22 \\
Households number & $(1.90)$ & $(1.92)$ \\
(\# members) & 0.69 & 0.12 \\
Income & $-0.11)$ & $(0.12)$ \\
(number of Minimum Wage) & $(0.31)$ & -0.50 \\
Hours worked weekly & -0.0001 & $(0.30)$ \\
Land title & $-0.0005)$ & 0.00001 \\
& $(0.004$ & $0.0003)$ \\
\hline$R^{2}$ & -6.82 & 0.002 \\
RootMSE & $(1.16)$ & $-7.05)$ \\
$\mathrm{N}$ & 0.20 & $(1.22)$ \\
\hline \hline & 7.07 & 0.20 \\
\hline
\end{tabular}

Table II: Child Labor and Land Title

(*) significant at $5 \%$

( ) Standard Error

Econometric results appear in Table II. This study default estimates include the entire set of regressors consistent with the current theory regarding child labor and land title and the data collected during the survey. In such specification, the estimate of land title $\delta$ coefficient is -6.82 , with a robust standard error of 1.16 .

Such outcome is highly consistent with our hypothesis, that property rights (Land Title) decreases child labor by fewer 6.82 hours worked per week. With a t-statistic of over 5 , the coefficient is different from zero at any reasonable level of statistical significance.

The Robustness part of the table provides our robustness check, adding (as mentioned previously) to the regression analysis, households that moved. The robustness outcome not only remains but also makes it even more significant (-7.26). Such result should help subsidize the conclusion that land title has a positive effect on the individuals not only on the property itself. Households that moved had the same attitude towards child labor.

Hence, the effect land title, given the conditions and variables applied, is clearly positive, and helps to minimize the number of weekly hours worked by children.

\section{Conclusion}

This paper has presented new evidence on the value of formal property rights in urban squatter community in a developing country. By studying the relationship between the exogenous acquisition of a land title and child labor force participation, the study has provided additional empirical 
support for the evidence that property title appear to reduce the household demand for child labor in the majority of the households.

Although existing studies indicate significant effect on access to credit, income, home investment and fertility Field (2007) and Andrade (2006), this particular study aims helping to fill an important gap in the literature on property rights and child labor force participation. Furthermore, the results indicate that unlike employment responses to most welfare programs, which tend to involve an income effect that potentially removes adult households from the labor force, government property titling programs appear to have a different effect - removes child labor from the labor force.

Regarding further research, it will certainly be interesting to apply the same survey in different locations and compare outcome results. Ravallion et al. (2005) argues that the same program works well in one village but fails in another. An example is the Bangladesh's Food for Education Program. The program worked well in reaching the poor villages but not in others, even in relatively close proximity. Furthermore, it will also add value keeping tracking the same households with other surveys to check consistency and robustness of the results overtime.

However, it is clear that understanding the multiple channels through which land titles influence economic outcome is a particular important given governments across the world are considering titling programs to address urban informality. In addition, the results have potential implications for understanding labor market frictions in developing countries (Goldsmith, 1995). In places characterized by high levels of residential informality such as most of developing and poor countries, informal property protection may constitute an important obstacle to labor market adjustment. Hence, land title could be applied as an asset to improve public policy actions that directly impact economic growth. 


\section{References}

ACEMOGLU, Daron; JOHNSON, Simon \& ROBINSON, James A. Reversal of Fortune: Geography and Institutions in the Making of the Modern World Income Distribution. The Quarterly Journal of Economics, vol. 117, No. 4, pp. 1231-1294, November 2002.

ALCHIAN, Armen \& DEMSETZ, Harold. The Property Rights Paradigm. The Journal of Economic History, vol. 33, No. 1, The Tasks of Economic History, pp. 16-27, March 1973.

ALSTON, Lee; LIBECAP, Gary \& SCHNEIDER, Robert. The Determinants and Impact of Property Rights: Land Titles on the Brazilian Frontier. Journal of Law, Economics 86 Organization, vol. 12, pp. 25-61, 1996.

ANDRADE, Maria T. Direitos de Propriedade e Renda Pessoal: Um Estudo de Caso das Comunidades do Caju. Revista do BNDES, Rio de Janeiro, vol.13, No. 26, pp. 261-274, 2006.

ASSOCIAÇÃO NACIONAL DOS REGISTRADORES DO ESTADO DE SÃO PAULO. Sistema de Biblioteca. Cartilha dos Registros Públicos. São Paulo: versão III, pp.03-05, 2007.

BAHAROGLU, Deniz. World Bank Experience in Land Management and the Debate on Tenure Security. World Bank Housing Research Background - Land Management Paper, July 2002.

BASU, Kaushik \& VAN, Pham Hoang. The Economics of Child Labor. American Economic Review, vol. 88, No. 3, pp. 412-27, 1998.

BECKER, Gary S.; LEWIS, H. Gregg. On the Interaction Between the Quantity and Quality of Children. Journal of Political Economy, vol. 81, No. 2, pp. S279-S288, 1973.

BERTRAND, Marianne; DUFLO, Esther \& MUlLAinATHAN, Sendhil. How Much Should We Trust Differences-in-Differences Estimates? Quarterly Journal of Economics, vol. 119(1), pp. 249-275, 2004.

BESLEY, Timothy. Property Rights and Investment Incentives: Theory and Evidence from Ghana. The Journal of Political Economy, vol.103, No. 5, pp. 903-937, 1995.

BHALOTRA, Sonia R.; HEADY, Christopher. Child Farm Labor: The Wealth Paradox. The World Bank Economic Review, vol. 17, No. 2, 2003.

BINSWANGER, Hans; DENINGER, Klaus \& FEDER, Gershon. Power, Distortions, Revolt, and Reform in Agricultural Land Relations. Handbook of Development Economics, vol. 42, pp. 26592772, 1995.

BOLFARINE; Heleno \& BUSSAB, Wilton. Elementos de Amostragem, $1^{\circ}$ ed., vol. 1. São Paulo: Edgar Blucher, 2005.

BRASSELLE, Anne-Sophie; GASPART, Frederic \& PLATTEAU, Jean-Philippe. Land Tenure Security and Investment Incentives: Puzzling Evidence from Burkina Faso. Journal of Development Economics, vol. 67, issue 2, pp. 373-418, April 2002.

CARTER, Michael \& OLINTO, Pedro. Getting Institutions Right for Whom? Credit Constraints and the Impact of Property Rights on the Quantify and Composition of Investment. American Journal of Agricultural Economics, vol. 85, pp. 173-186, 2003. 
CARTER, Michael \& ZEGARRA, Eduardo. Land Markets and the Persistence of Rural Poverty in Latin America: Conceptual Issues, Evidence and Policies in the Post-Liberalization Era. In: LOPEZ, R. \& VALDES, A. (orgs). Rural Poverty in Latin America: Analytics, New Empirical Evidence and Policy. Basingstoke, UK: MacMillan Press, 2000.

COCKBURN, Julio A. Regularization of Urban Land in Peru. Land Lines, Lincoln Institute of Land Policy. Cambridge, Massachusetts, USA, 1998.

DE SOTO, Hernando. O Mistério do Capital. Rio de Janeiro: Record, 2000.

DEMSETZ, Harold. Toward a Theory of Property Rights. The American Economic Review, vol. 57, issue 2, pp. 347-359, May 1967.

DO, Quy-Toan \& IYER, Lakshmi. Land rights and economic development: evidence from Vietnam. Policy Research Working Paper Series 3120, The World Bank, 2003.

EMERSON, Patrick M.; SOUZA, André P. Is There a Child Labor Trap? Inter-Generational Persistence of Child Labor in Brazil. Economic Development and Cultural Change, vol. 51, No. 2, pp. 375-398, 2003.

FIELD, Erica. Entitle to Work: Urban Property Rights and Labor Supply in Peru. The Quarterly Journal of Economics, vol. 122, No. 4, Pages 1561-1602, November 2007.

FIELD, Erica \& TORERO, Maximo. Do Property Titles Increase Credit Access among the Urban Poor? Evidence from Peru. Research Program in Development Studies, Working Paper No. 223, Princeton University, 2002.

GOLDSMITH, Arthur A. Democracy, Property Rights and Economic Growth. Journal of Development Studies, vol. 32(2), pp. 157-174, 1995.

GREENE, William H. Econometric Analysis. New York, NY: Prentice Hall, 2002.

GROOTAERT, Christiaan. Child Labor in Côte d'Ivoire. In: GROOTAERT, C.; PATRINOS, H. (Ed.). The Policy Analysis of Child Labor: A Comparative Study. World Bank, Washington, DC, 1998.

HEADY, Christopher. The Effect of Child Labor on Learning Achievement. World Development, vol. 31, No. 2, pp. 385-398, 2003. Elsevier Science.

HECKMAN, James \& HOTZ, Joseph. Choosing Among Alternative NX Methods for Estimating the Impact of Social Programs: The Case of Manpower Training. Journal of the American Statistical Association, vol. 84, pp. 862-874, 1989.

The International Labour Organization. International Labor Review, vol. 141, No. 1-2, 2002.

JACOBY, Hanan G. LI, Guo \& ROZELLE, Scott. Hazards of Expropriation: Tenure Insecurity and Investment in Rural China. American Economic Review, vol. 92, issue 5, pp. 1420-1447, 2002.

JIMENEZ, Emmanuel. Tenure Security and Urban Squatting. Review of Economics and Statistics, vol. 66, issue 4, pp. 556-567, November 1984. 
JIMENEZ, Emmanuel. Urban Squatting and Community Organization in Developing Countries. Journal of Public Economics, vol. 27, pp. 69-92, 1985.

KASSOUF, Ana L. Aspectos Sócio-Econômicos do Trabalho Infantil no Brasil. 123p. Ministério da Justiça, Secretaria de Estado dos Direitos Humanos. Brasília, 2002.

LANJOUW, Jean O. \& LEVY, Philip. Untitled: A Study of Formal and Informal Property Rights in Urban Ecuador. The Economic Journal, vol. 112 (482), pp. 986-1019, 2002.

MEYER, Bruce. Natural and Quasi-Natural Experiments in Economics. Journal of Business and Economic Statistics, vol. XII, pp. 151-162, 1995.

MICELI, Thomas J.; SIRMANS, C. F. \& KIEYAH, Joseph. The Demand for Land Title Registration: Theory with Evidence from Kenya. American Law and Economics Review, vol. 3, No. 2, pp. 275-287, 2001.

NORTH, Douglass C. Institutions, institutional change and economic performance. Cambridge: Cambridge University Press, 1990.

NORTH, Douglass C. \& THOMAS, Richard P. The Rise of the Western World: A New Economic History. Cambridge: Cambridge University Press, 1973.

PATRINOS, Harry A.; PSACHAROPOULOS, George. Educational Performance and Child Labor in Paraguay. International Journal of Educational Development, vol. 15, pp. 47-60, 1994.

PLACE, Frank \& MIGOT-ADHOLLA, Shem. The Economic Effects of Land Registration for Smallholder Farms in Kenya: Evidence from Nyeri and Kakamega Districts. Land Economics, vol. 74, No. 3, pp. 360-373, August 1998.

PNAD - Síntese dos Indicadores 2007. Microdados. IBGE, Rio de Janeiro, 2008. Available at: <http://www.ibge.gov.br/home/estatistica/populacao/trabalhoerendimento/pnad2007/sintesepnad2007.pdf>. Acess on Sep, 28th 2008.

PREFEITURA DE OSASCO. Sistemas de Bibliotecas. Roteiro para Áreas Públicas Ocupadas Programa de Regularização da Prefeitura de Osasco. Osasco: Ed. Municipal, 2006.

Property Rights: China's Next Revolution? In: The Economist, Mar, 12th 2007.

RAVALLION, Martin; GALASSO, Emanuela; LAZO, Teodro \& PHILLIP, Ernesto. What Can Ex-Participants Reveal About a Program's Impact? Journal of Human Resources, vol. 40, pp. 208-230, 2005.

RAVALLION, Martin; WALLE, Dominique van de \& GAURTAM, Madhur. Testing a Social Safety Net. Journal of Public Economics, vol. 57(2), pp. 175-199, 1995.

RAY, Ranjan. Child Labor, Child Schooling and their Interaction with Adult Labor. The World Bank Economic Review, vol. 14(2), pp. 347-367, 1999.

ROSENZWEIG, Mark. Household and Non-Household Activities of Youths: Issues of Modelling, Data and Estimation Strategies. In: RODGERS, Gerry; STANDING, Guy. (Ed.). Child work, poverty and underdevelopment. ILO, Genebra, 1981. 
RUBIN, Donald \&.Thomas, N. Combining Propensity Score Matching With Additional Adjustments for Prognostic Covariates. Journal of the American Statistical Association, vol. 95, pp. 573-585, 2000.

TORSTENSSON, Johan. Property Rights and Economic Growth: An Empirical Study. Kiklos, vol. 47, issue 2, pp. 231-247, 1994.

UNITED NATIONS REPORT, Habitat Report, 2005.

WAHBA, Jackline. The Influence of Market Wages and Parental History on Child Labor and Schooling in Egypt. University of Southampton, Dep. of Economics. 2002. (Working Paper).

World Bank Development New Archives, Peru. Urban Poor Gain Access to Property Market, February $2,2000$. 